\title{
Preventative medicine: The next revolution in the treatment of aortic stenosis
}

\author{
John J. Squiers, BSE, ${ }^{\mathrm{a}}$ Katherine B. Harrington, MD, ${ }^{\mathrm{b}}$ Mani Arsalan, MD, ${ }^{\mathrm{b}, \mathrm{c}}$ and J. Michael DiMaio, MD ${ }^{\mathrm{a}, \mathrm{b}}$
}

\footnotetext{
From the ${ }^{\mathrm{a}}$ Baylor Research Institute, Baylor Healthcare System, Dallas, Tex; ${ }^{\mathrm{b}}$ The Heart Hospital Baylor Plano, Baylor Healthcare System, Plano, Tex; and the ${ }^{\mathrm{c}}$ Department of Cardiac Surgery, Kerckhoff Clinic Heart Center, Bad Nauheim, Germany.

Disclosures: Authors have nothing to disclose with regard to commercial support.

Received for publication Sept 30, 2015; accepted for publication Oct 1, 2015; available ahead of print Oct 23 , 2015 .

Address for reprints: J. Michael DiMaio, MD, Baylor Healthcare System, 6125 Luther Ln, Dallas, TX 75225 (E-mail: jmdimaio@yahoo.com).

J Thorac Cardiovasc Surg 2016;151:263-4

$0022-5223 / \$ 36.00$

Copyright (c) 2016 by The American Association for Thoracic Surgery

http://dx.doi.org/10.1016/j.jtcvs.2015.10.005
}

Calcific aortic stenosis (AS) has been the most common indication for surgical valve replacement in the developed world for decades. ${ }^{1}$ The pathophysiology of aortic valve (AV) calcification is driven by 3 interrelated mechanisms ${ }^{2}$ : (1) classical cardiovascular risk factors, ${ }^{3}$ (2) genetic factors, ${ }^{4}$ and (3) valve cellular biology. ${ }^{5}$ Although AV calcification was long believed to be a passive process ("degenerative" valve disease), a growing body of literature has demonstrated that the progression of calcification on the AV is actively regulated.

The natural progression of calcific AV disease was first described by Otto and colleagues. ${ }^{7}$ The initial stage of AV calcification, called valve sclerosis, is associated with focal leaflet thickening that leads to calcification without hemodynamic consequences. ${ }^{8}$ Eventually leaflet thickening and calcification obstruct the left ventricular outflow tract, causing hemodynamic changes and a resulting diagnosis of AS. Notably, aortic sclerosis is slow to progress to $\mathrm{AS},{ }^{9}$ which is the primary reason AS is typically considered a disease of the elderly. AS ultimately leads to heart failure, and the major predictor of mortality for this pathology is the onset of associated symptoms, left ventricular dysfunction, or both. ${ }^{10}$ Despite the rapid growth in our understanding of the etiology of $\mathrm{AV}$ calcification, no preventive strategy for AS is currently available.

Currently, there are an estimated 500,000 elderly people (age $\geq 75$ years) with severe symptomatic AS living in the United States, a number that is expected to triple by $2050 .^{11}$ For many years, the only available therapy for calcific AS was surgical AV replacement (SAVR). ${ }^{12}$ SAVR has been demonstrated to be effective in reducing symptoms and increasing survival, ${ }^{13}$ with low operative mortality in select patients. ${ }^{14}$ As many as $30 \%$ of patients with severe symptomatic AS, however, are not offered surgical intervention because of their high surgical risk as a result of advanced age, left ventricular dysfunction, more revolutionary. calcification.

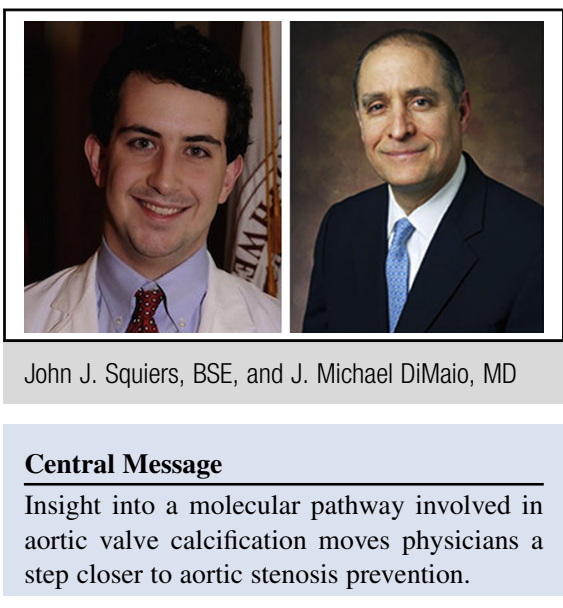

See Article page 255 .

or problematic comorbidities. ${ }^{15}$ During the last decade, transcatheter AV replacement (TAVR) has become increasingly available for patients with severe AS who are not surgical candidates or are at believed to be at too-high risk to undergo SAVR. ${ }^{16,17}$ Despite the rightful enthusiasm surrounding the ascent of TAVR, however, a strategy to prevent the development of AS would be even

In this issue of the Journal, Wang and colleagues ${ }^{18}$ present work that further elucidates the molecular signaling pathways regulating AV calcium deposition. Wang and colleagues ${ }^{18}$ hypothesized that high-mobility group box-1 protein (HMGB1), a molecule that has been implicated in the pathogenesis of vascular atherosclerosis and inflammatory changes, ${ }^{19}$ may also be involved in AV calcification. HMGB1 is a key agonist of Toll-like receptor 4 (TLR4), ${ }^{20}$ which is known to stimulate osteoblastic differentiation of valvular interstitial cells. ${ }^{21}$ Pro-osteogenic differentiation of these cells is believed to promote calcium deposition on the $\mathrm{AV}$, so Wang and colleagues ${ }^{18}$ attempted to delineate the relationship of HMGB1 and TLR4 with AV

Wang and colleagues ${ }^{18}$ collected calcified AV leaflets from 15 patients undergoing SAVR because of severe AS and "normal" AV leaflets from 10 patients undergoing a Bentall procedure for acute aortic dissection. First, through immunohistochemical staining of these samples, they found that both HMBG1 and TLR4 expressions were increased in the calcific AVs. Then, by conducting a series of experiments, Wang and colleagues ${ }^{18}$ were able to outline several 
steps in a HMGB1/TLR4 pathway that ultimately promoted osteoblastic differentiation, inflammation, and calcification in cultured valvular interstitial cells. In their study, Wang and colleagues ${ }^{18}$ did not identify the source of the HMGB1 during the development of AV calcification, nor could they confirm that the pathway of interest is the sole mechanism through which HMGB1 affects this disease process. Nevertheless, their work indeed does implicate HMGB1 in the pathogenesis of calcific AV disease.

By furthering our understanding of the molecular pathways promoting the calcification of AV leaflets, Wang and colleagues ${ }^{18}$ have moved medicine a step closer to the next revolution in the treatment of AS-its prevention. Future work stemming from this report should attempt to gain additional insights into the molecular mechanisms of AV calcification. Eventually, these molecular pathways can be traced back to genetic factors that place certain patients at increased risk for the eventual development of AS. By identifying susceptible patients early and targeting the HMGB1/TLR4 pathway or some other pathway with preventative therapy, physicians could begin to eliminate the burden of AS altogether.

\section{References}

1. Lindroos M, Kupari M, Heikkilä J, Tilvis R. Prevalence of aortic valve abnormalities in the elderly: an echocardiographic study of a random population sample. J Am Coll Cardiol. 1993;21:1220-5.

2. Rajamannan NM. Calcific aortic stenosis: lessons learned from experimental and clinical studies. Arterioscler Thromb Vasc Biol. 2009;29:162-8.

3. Stewart BF, Siscovick D, Lind BK, Gardin JM, Gottdiener JS, Smith VE, et al. Clinical factors associated with calcific aortic valve disease. Cardiovascular Health Study. J Am Coll Cardiol. 1997;29:630-4.

4. Garg V, Muth AN, Ransom JF, Schluterman MK, Barnes R, King IN, et al. Mutations in NOTCH1 cause aortic valve disease. Nature. 2005;437:270-4.

5. Mohler ER III, Gannon F, Reynolds C, Zimmerman R, Keane MG, Kaplan FS. Bone formation and inflammation in cardiac valves. Circulation. 2001;103:1522-8.

6. Miller JD, Weiss RM, Heistad DD. Calcific aortic valve stenosis: methods, models, and mechanisms. Circ Res. 2011;108:1392-412.
7. Otto CM, Kuusisto J, Reichenbach DD, Gown AM, O'Brien KD Characterization of the early lesion of 'degenerative' valvular aortic stenosis Histological and immunohistochemical studies. Circulation. 1994;90:844-53.

8. Iung B, Vahanian A. Degenerative calcific aortic stenosis: a natural history. Heart. 2012;98(Suppl 4):iv7-13.

9. Cosmi JE, Kort S, Tunick PA, Rosenzweig BP, Freedberg RS, Katz ES, et al. The risk of the development of aortic stenosis in patients with "benign" AV thickening. Arch Intern Med. 2002;162:2345-7.

10. Rosenhek R, Zilberszac R, Schemper M, Czerny M, Mundigler G, Graf S, et al. Natural history of very severe aortic stenosis. Circulation. 2010;121:151-6.

11. Osnabrugge RL, Mylotte D, Head SJ, Van Mieghem NM, Nkomo VT, LeReun CM, et al. Aortic stenosis in the elderly: disease prevalence and number of candidates for transcatheter AV replacement: a meta-analysis and modeling study. J Am Coll Cardiol. 2013;62:1002-12.

12. Ross J Jr, Braunwald E. Aortic stenosis. Circulation. 1968;38(1 Suppl):61-7.

13. Lund O. Preoperative risk evaluation and stratification of long-term survival after valve replacement for aortic stenosis: reasons for earlier operative intervention. Circulation. 1990;82:124-39.

14. O'Brien SM, Shahian DM, Filardo G, Ferraris VA, Haan CK, Rich JB, et al; Society of Thoracic Surgeons Quality Measurement Task Force. The Society of Thoracic Surgeons 2008 cardiac surgery risk models: part 2-isolated valve surgery. Ann Thorac Surg. 2009;88(1 Suppl):S23-42.

15. Dewey TM, Brown D, Ryan WH, Herbert MA, Prince SL, Mack MJ. Reliability of risk algorithms in predicting early and late operative outcomes in high-risk surgical patients undergoing aortic valve replacement. J Thorac Cardiovasc Surg. 2008;135:180-7.

16. Leon MB, Smith CR, Mack M, Miller DC, Moses JW, Svensson LG, et al. Transcatheter aortic-valve implantation for aortic stenosis in patients who cannot undergo surgery. N Engl J Med. 2010;363:1597-607.

17. Smith CR, Leon MB, Mack MJ, Miller DC, Moses JW, Svensson LG, et al. Transcatheter versus surgical aortic-valve replacement in high-risk patients. N Engl J Med. 2011;364:2187-98.

18. Wang B, Li F, Zhang C, Wei G, Liao P, Dong N. High mobility group box-1 protein induces the osteogenic phenotype changes aortic valve interstitial cells. J Thorac Cardiovasc Surg. 2016;151:255-62.

19. de Souza AW, Westra J, Limburg PC, Bijl M, Kallenberg CG. HMGB1 in vascular disease: its role in vascular inflammation and atherosclerosis. Autoimmun Rev. 2012;11:909-17.

20. Yang H, Hreggvidsdottir HS, Palmblad K, Wang H, Ochani M, Li J, et al. A critical cysteine is required for HMBG1 binding to Toll-like receptor 4 and activation of macrophage cytokine release. Proc Natl Acad Sci U S A. 2010; 107:11942-7.

21. Yang X, Fullerton DA, Su X, Ao L, Cleveland JC Jr, Meng X. Pro-osteogenic phenotype of human aortic valve interstitial cells is associated with high levels of Toll-like receptors 2 and 4 and enhanced expression of bone morphogenetic protein 2. J Am Coll Cardiol. 2009;53:491-500. 